\title{
Responses to organic and inorganic selenium in the performance and blood selenium content of growing pigs
}

\author{
Kaija Suomi and Timo Alaviuhrola
}

\begin{abstract}
Suomi, K. \& Alaviuhrola, T. 1992. Responses to organic and inorganic selenium in the performance and blood selenium content of growing pigs. Agric. Sci. Finl. 1: 211-214. (Agric. Res. Centre of Finland, Swine Res. Sta., SF-05840 Hyvinkää, Finland.)
\end{abstract}

\begin{abstract}
An experiment was carried out with 36 growing pigs in order to compare their responses to organic selenium and inorganic selenium. No significant differences were found in daily gain, feed/gain ratio or carcass quality of growing pigs fed with $0.1 \mathrm{mg}$ inorganic Se or the same amount of Se bound in yeast. Neither were there significant differences in the content of Se in the liver and serum between these Se sources. The amount of $0.4 \mathrm{mg}$ yeast selenium in the feed increased the Se level in the serum and liver significantly as compared to a lower level of supplementation $(0.1 \mathrm{mg})(\mathrm{p}<0.001)$.
\end{abstract}

Key words: growing pig, organic $\mathrm{Se}$, inorganic Se

\section{Introduction}

The effects of organic and inorganic Se on pigs have been studied widely (CARY et al. 1973, MAHAN and MoXon 1978, GoEHring et al. 1984 a, KURKELA and KÄÄNTEE 1984). In the studies by MAHAN and MOXON (1978) and CARY et al. (1973), no differences could be found in the effects of organic or inorganic Se on pigs at a level below 0.1 $\mathrm{mg} / \mathrm{kg}$ feed, when using the Se retention by the tissues as a criterion. If the Se content of the feed exceeded $0.1 \mathrm{mg}$, the retention of organic Se by tissues was higher compared to the retention of inorganic Se. In contrast to this, the availability of inorganic Se for glutathione peroxidase enzyme (GSH$\mathrm{Px}$ ) was higher compared to organic Se (GoEHRING et al. 1984a and SANKARI 1985).

In the commercial feed mixtures in Finland inorganic Se is mainly used in the form of sodium selenite and/or organic $\mathrm{Se}$ in the form of selenomethionine. Selenium of plant origin occurs mainly in the form of selenomethionine (LANTSHAW and OSMAN, 1975).

Alkosel is an organic Se-enriched yeast developed from ordinary baker's yeast by replacing the sulphur in the yeast compounds with Se (KORHOLA et al. 1986). When the yeast is grown in the absence of a source of inorganic sulphur and inorganic Se (selenium dioxide) is added instead, the Se is incorporated into analogues of sulphur containing amino acids (VARIMO et al. 1983). The Se content of ordinary baker's yeast is about $40 \mu \mathrm{g} / \mathrm{kg} \mathrm{DM}$ and its sulphur content $3.6 \mathrm{~g} / \mathrm{kg}$ DM, Se-enriched yeast contains about $500 \mathrm{mg} / \mathrm{kg} \mathrm{DM}$ of Se. The Se is mostly in the form of selenomethionine in the selenium yeast (KORHOLA et al. 1986). According to VARIMO et al. (1983), $80 \%$ of the Se in Se-enriched yeast is in organic form.

The objective of this study was to determine the responses of growing pigs to organic Se-enriched yeast produced by Alko Ltd. as a source of selenium. 


\section{Material and methods}

A performance experiment was conducted with 36 Landrace and Yorkshire pigs, which were divided into three different treatment groups at the age of 10 weeks according to weight, litter and breed. Each treatment included an equal number of female and castrated pigs. Two females or two castrates were kept in the same pen. The average initial weight of the pigs was $25 \mathrm{~kg}$, and they were sent for slaughter at a liveweight of $95 \mathrm{~kg}$.

The three experimental diets contained the same amount of barley $(79.0 \%)$, soybean meal $(15.5 \%)$, fish meal $(2 \%)$ and mineral and vitamin mixture $(3.5 \%)$. The calculated digestible crude protein content of the diets was $13.9 \%$. Se was added to the diet of both the first (control) and the second treatment group at a rate of $0.1 \mathrm{mg} / \mathrm{kg}$ of feed mixture in the form of selenodioxide (control group) or selenium yeast (group 2). The diet of the third treatment group was supplemented with Se in the form of selenium yeast at a rate of $0.4 \mathrm{mg} / \mathrm{kg}$. The total Se content of the diets, calculated from the analyzed Se content of the raw materials, was $0.3,0.3$ and $0.6 \mathrm{mg} / \mathrm{kg}$, respectively.

A restricted feeding scale from 1.4 to 2.9 FU/day/animal was used. Animals were fed twice a day. Feed consumption was registered daily and the growth rate weekly during the experiment. At the end of the experiment, blood samples were taken from all animals and liver samples from six animals in each treatment group. The Se content of the blood serum and the liver was analyzed according to the methods of WELZ et al. (1984) and of KUMPULAINEN and SAAREJA (1991), respectively.

The mean results of the treatments were statistically tested by one-way analyses of variance, and the significance of the differences of the means was determined by Tukey's test.

\section{Results and discussion}

No differences were found between the Se sources or the level of Se supplementation with respect to pig performance or carcass quality (Table 1).
Table 1. Performance, carcass quality and Se content of the blood serum and liver of pigs on different Se feeding. Mean of the treatment groups $(\mathrm{n}=12)$.

Se source

Se-dioxide Se-enriched yeast $\mathrm{SEM}^{3}$

Level of

supplementation

$\mathrm{mg} / \mathrm{kg}$ feed

0.1

0.1

0.4

\begin{tabular}{|c|c|c|c|c|}
\hline Daily weight gain, $\mathrm{g}$ & 839 & 850 & 841 & 25 \\
\hline \multicolumn{5}{|l|}{ Feed conversion rate } \\
\hline FU/kg gain ${ }^{1}$ & 2.76 & 2.73 & 2.72 & 0.08 \\
\hline Side fat,mm & 17.0 & 16.4 & 15.5 & 1.18 \\
\hline Meat percentage & 51.0 & 51.2 & 51.5 & 0.7 \\
\hline \multicolumn{5}{|l|}{ Se in the blood serum } \\
\hline$\mu \mathrm{g} / \mathrm{l}^{2}$ & $174^{a}$ & $183^{a}$ & $212^{\mathrm{b}}$ & 5.1 \\
\hline $\begin{array}{l}\text { Se in the liver, } \\
\mu \mathrm{g} / \mathrm{kg}^{2}\end{array}$ & $2400^{\mathrm{a}}$ & $2588^{a}$ & $3781^{b}$ & 126.6 \\
\hline
\end{tabular}

1. $\mathrm{FU}=0.7 \mathrm{~kg}$ starch equivalent

2. $\mathrm{a}-\mathrm{b}=\mathrm{P}<0.001$

3. $\mathrm{SEM}=$ standard error of the means.

GoeHring et al. (1984 a) were also unable to find any differences in the performance of pigs fed with organic or inorganic Se at a rate of up to $8.33 \mathrm{mg} / \mathrm{kg}$ feed.

The addition of Se at a rate of $0.1 \mathrm{mg} / \mathrm{kg}$ to the diets as selenium oxide or Se-enriched yeast did not cause any differences in the blood plasma or the liver Se content. However, when the amount of Se added was increased to a level of $0.4 \mathrm{mg} / \mathrm{kg}$ feed in the organic form, the Se content of the blood plasma and the liver was significantly higher than at the lower level of supplementation $(\mathrm{p}<0.001)$. GoEHring et al. (1984 b) report that the Se content of blood plasma increased linearly with the increasing Se level of the feed up to $20 \mathrm{mg} / \mathrm{kg}$. In another study by the same authors, the Se content of the liver was found to increase linearly with the increasing level of inorganic (sodium selenite, $0.54-8.33$ $\mathrm{mg} \mathrm{Se} / \mathrm{kg}$ feed) or organic Se (plant selenium, 0.47 $-8.40 \mathrm{mg} \mathrm{Se} / \mathrm{kg}$ feed) in the feed (GoEHrING et al. 1984 a).

The results of the present study are in accordance with those of KURKELA and KÄÄNTEE (1984), who found no differences in the Se contents in blood plasma or the liver when the Se was given to the pigs in organic or inorganic form at a dietary level 
of $0.27 \mathrm{mg} / \mathrm{kg}$ DM. The Se content in muscular tissue was 2.5 times higher when organic Se was used in the study of KURKELA and KÄÄNTEE (1984).

According to CARY et al. (1973), excess inorganic Se can be eliminated from the body, whereas excess organic $\mathrm{Se}$ is incorporated into the body proteins. GoEHring et al. (1984 a) could not find any decrease in the growth rate of pigs when $\mathrm{Se}$ was supplemented to the diet at a rate of up to 8.4 $\mathrm{mg} / \mathrm{kg}$ either in organic or inorganic form. According to these authors, the first sign of chronic selenosis is retarded gain (GoEHring et al. 1984 b). Organic dietary Se supplementation is a more efficient way of increasing the Se content of the meat as compared to inorganic Se supplementation (MOKSNES et al. 1982).

In Finland, pig feeds contain organic Se from Se- fertilized grain and also from inorganic Se supplementation at $0.1 \mathrm{mg} / \mathrm{kg}$ in complete feed mixtures. According to Finnish legislation, the highest permissible content in complete feeds is $0.3 \mathrm{mg} \mathrm{Se} / \mathrm{kg}$ (MMM 1986). The purpose of the Se fertilization was to increase the Se supply for humans. The Se requirement of pigs is already met by inorganic $\mathrm{Se}$ supplementation alone. According to SANKARI (1990) the average total amount of Se in complete feed mixtures $(0.33 \mathrm{mg} / \mathrm{kg})$ exceeds the upper limit of Se in feeds $(0.3 \mathrm{mg} / \mathrm{kg})$. More recently the Se content of Finnish the fertilizers has been reduced from $16 \mathrm{mg} / \mathrm{kg}$ to $6 \mathrm{mg} / \mathrm{kg}$.

In conclusion, the results of the present study show that Se-enriched yeast is as effective a source of Se as inorganic Se (selenium dioxide) to meet the Se requirement of pigs.

\section{References}

Cary, E.E., Allaway, W.H. \& Miller, M. 1973. Utilization of different forms of dietary selenium. J. Anim. Sci. 36: 285-292.

Chavez, E.R. 1989. Selenium nutririon of pigs: a review. Pig News Inf. 10: 167-171.

Goehring, T.B., Palmer, I.S., Olson, O.E., Libal, G.W. \& WAHLSTROM, R.C. 1984 a. Effects of seleniferous grains and inorganic selenium on tissue and blood composition and growth performance of rats and swine. J. Anim. Sci. 59: 725-732.

-, Palmer, I.S., Olson, O.E., Libal, G.W. \& Wahlstrom, R.C. 1984 b. Toxic effects of selenium on growing swine fed corn - soybean meal diets. J. Anim. Sci. 59: 733-737.

Korhola, M., Vainio, A. \& Edelmann, K. 1986. Selenium yeast. Ann. Clin. Res. 18: 65-68.

Kumpulainen, J. \& SaAreja, K.-E. 1991. Determination of selenium in staple foods and total diets by etaas without solvent extraction. XXVII Colloquium Spectroscopicum Internationale, Bergen, Norway. Book of Abstracts B-6.5.

Kurkela, P. \& KÄÃNTEE, E. 1984. Effects of barley - bound organic selenium compared with inorganic selenite on selenium concentration and structure of tissues in pig. $\mathbf{J}$. Agric. Sci. Finl. 56: 61-72.

Lantshaw, J.D. \& Osman, M. 1975. Distribution of selenium in egg White and yolk after feeding natural and synthetic selenium compounds. Poultry Sci. 54: 12441252.

Mahan, D.C. \& Moxon, A.L. 1978. Effects of adding inor- ganic or organic selenium sources to the diets of young swine. J. Anim. Sci. 47: 456-466.

MMM 1986. Maa- ja metsătalousministeriön päătös hyväksytyistä rehun lisăaineista Nro 381. Suomen Săådőskokoelma Nro 376-384. p. 872-879.

Moksnes, K., Tollersrud, S. \& LarSen, H.J. 1982. Influence of dietary sodium selenite on tissue selenium levels of growing pigs. Acta vet. scand. 23: 361-367.

SANKARI, S. 1985. Plasma glutathione peroxidase and tissue selenium response to selenium supplementation in swine. Acta vet. scand. 81: 1-127.

- 1990. Näkökohtia seleenistă sikojen rehussa. Sika 2: 2829.

Varimo, K., harju, K., Edelmann, K. \& Korhola, M. 1983. Seleenipitoinen hiiva. Kemia - kemi. 10: 1049. 1050.

Welz, B., Schlemmer, G. \& Völlkoph, U. 1984. Influence of the valency state on the determination of selenium graphite furnace atomic absorption spectrometry. Spectrochimica Acta 39 (B): 501-510.

\section{Manuscript received December 1991}

Kaija Suomi

Timo Alaviuhkola

Agricultural Research Centre of Finland

Swine Research Station

SF-05840 Hyvinkäă, Finland 


\title{
SELOSTUS
}

\section{Orgaanisen ja epäorgaanisen seleenin hyväksikäyttö lihasioilla}

\author{
Kaija SuOmi ja Timo Alaviuhrola \\ Maatalouden tutkimuskeskus
}

Kasvavien sikojen rehuun lisättiin seleeniä $0.1 \mathrm{mg} / \mathrm{kg}$ joko epäorgaanisena, seleenidioksidina $=\mathrm{I}$ vertailuryhmä, tai orgaanisena,seleenihiivana $=$ II ryhmä. Seleenihiivaa lisättiin myös $0.4 \mathrm{mg} / \mathrm{kg}$ rehua $=$ III ryhmä. Seleenihiiva oli Alko Ltd:n tuottama Alkosel niminen hiiva. Se on kehitetty tavallisesta leipomohiivasta korvaamalla osa hiivan rikistă seleenillä. Seleenihiivassa on seleeniä 10000 kertaa enemmän kuin tavallisessa hiivassa eli $500 \mathrm{mg} / \mathrm{kg}$ ka. Seleenihiivan seleeni on $80 \%$ :sti orgaanisesti sitoutunutta, pääasiassa selenometioniinia.

Eri määrillä tai eri lähteistä peräisin olevalla seleenillä ei ollut vaikutusta sikojen kasvuun, rehun hyväksikäyttöön tai teurastuloksiin. Seleenihiivalla, varsinkin korkeammalla tasolla, sikojen seerumin ja maksan seleenipitoisuudet olivat korkeammat kuin seleenidioksiidilla.

Seleenihiivan todettiin olevan seleenidioksiidin kanssa samanarvoisen sikojen lisäseleenilähteenä. 